\title{
French Studies: An Antidote to Covid 19 Pandemic
}

\author{
Oluoyeneye, R. A. \\ Department of French, Federal College of Education, Abeokuta
}

\begin{abstract}
This research work sought to assess the French studies: an antidote to Covid 19 pandemic. In order to carry out this study, three research questions were raised. The survey research design, using the descriptive method was employed in the study. One hundred students were selected from Odeda Local Government area of Ogun State. Data obtained were analyzed using mean and standard deviation. The find revealed that effect of Coronavirus on academic performance of students in secondary school in Odeda Local Government Area of Ogun State and also shows teacher attitude towards the impact of Coronavirus on academic performance of students in secondary school in Odeda Local Government Area of Ogun State. From the find it is revealed that students' attitudes towards the impact of Coronavirus on academic performance of students in secondary school in Odeda Local Government Area of Ogun State. Recommendations were offered and were as follows; the federal government should intensify prevention and control measures by ensuring that all states comply with the Federal government preventive orders in order to ensure uniformity of purpose, the government should look into the modalities adopted for relief distribution across the states, with the aim of ensuring that reliefs get to the target audience and government might need to explore house to house testing of residents especially in states with high level of prevalence.
\end{abstract}

DOI: $10.7176 /$ JLLL/81-02

Publication date:August $31^{\text {st }} 2021$

\section{Introduction}

Coronavirus disease 2019 (COVID-19), which was first identified in Wuhan city in East China in December 2019 (Zhu et al., 2020), has spread at an alarming rate and become a major challenging global public health problem (Phelan et al., 2020). In response to this pandemic situation, the World Health Organization (WHO) declared a public health emergency of international concern on January 30, 2020 (World Health Organization 2020). Although the mortality rate of COVID-19 outside China was initially rather low (Kang, 2020), leading to the expectation that the effect of the disease on the health of individuals in other countries would be minor, this view rapidly changed. In France, the most recent reports of laboratory-confirmed COVID-19 cases and deaths are as follows: through July 15, 2020, a total of 174674 patients were diagnosed with confirmed cases, of whom 30152 died due to COVID-19 and 79244 recovered and were discharged from hospitals. Since March 15, 2020, some unprecedented measures have been adopted in France with the intention of controlling COVID-19 transmission and avoiding contact with others. As in many countries, officials with the French government have announced the closure of schools, colleges, universities and other educational institutions to prevent the rapid spread of COVID-19 by disrupting important chains of transmission (Sahu, 2020). According to monitoring by the United Nations Educational, Scientific and Cultural Organization (UNESCO), the closure of educational institutions impacted over $87 \%$ of the student population worldwide (De Oliveira et al., 2020). Students, as well as universities, became uncertain about how online teaching would be delivered, such as the procedures for assessments, projects and semester-end final examinations (Sahu, 2020). This situation has created a sense of uncertainty, stress and anxiety that might lead to unfavourable outcomes regarding the psychological health of students (Al-Rabiaah et al., 2020). Several other measures were also implemented, including travel restrictions, social distancing, and closures of restaurants, movie theatres, gyms, museums, and other places involving potential gatherings, leading students to protect themselves from any person-to-person contact and to live in selfisolation until the situation became normal. Based on a number of recent studies, students have been identified as a vulnerable group that experiences significant levels of stress-related mental health concerns, including anxiety and depression (Regehr et al., 2013). Thus, before the pandemic started, one in five college students worldwide had experienced one or more diagnosable mental disorders (Auerbach et al., 2016; Zhai et al., 2020). According to previous research, individuals experience negative emotional responses, such as anxiety and depression symptoms, during an outbreak (Zhou et al., 2020), and stressful events and public health emergencies such as the COVID-19 outbreak are potent adverse environmental factors that may exert greater psychological effects on students that are expressed as anxiety, fear and worry (Mei et al., 2011; Liu et al., 2020; Fiorillo et al.,2020; Wang and Zhao, 2020). A recent study among Chinese college students revealed that $24.9 \%$ experienced anxiety because of this COVID-19 outbreak. Overall, living in urban areas, living with parents and having a steady family income were identified as protective factors against anxiety in college students, while having a relative or an acquaintance infected with COVID-19 was an independent risk factor for experienced anxiety (Cao et al., 2020). Similarly, a study reported increased scores for anxiety, depression, and suicidal thoughts, worsened 
quality of life and decreased quality of sleep among Greek students during the lockdown (Kaparounaki et al., 2020). The studies will observed the French studies: an antidote to Covid 19 pandemic, there is efforts to stem the spread of COVID-19 through non-pharmaceutical interventions and preventive measures such as socialdistancing and self-isolation have prompted the widespread closure of primary, secondary, and tertiary schooling in over 100 countries. Previous outbreaks of infectious diseases have prompted widespread school closings around the world, with varying levels of effectiveness.(Jordan, 2020) Mathematical modelling has shown that transmission of an outbreak may be delayed by closing schools. However, effectiveness depends on the contacts children maintain outside of school. School closures may be effective when enacted promptly.

\section{Objectives of the Study}

The specific objectives are:

1. To determine the extent to effect of COVID19 Pandemic on the academic performance of French studies.

2. To identify the effects of teacher attitude towards the impact of COVID19 Pandemic on the academic performance of French studies.

3. To determine effects of students' attitude towards the impact of COVID19 Pandemic on the academic performance of French studies.

\section{Research Questions}

The following are the guided research questions:

1. What are the effects of COVID19 Pandemic on the academic performance of French studies?

2. Does the effects of teacher attitude towards the impact of COVID19 Pandemic on the academic performance of French studies?

3. Does effects of student's attitude towards the impact of COVID19 Pandemic on the academic performance of French studies?

\section{Methodology}

The descriptive survey research approach was adopted for this study. The population for this research involved all the secondary school teachers in Odeda local government, Ogun state. Stratified random sampling was used to select a total of 100 teachers from 5 selected schools in Odeda Local Government. A four-point scale Likerttype questionnaire develop by the researcher was used for data collection. It contains 2 sections A and B. Section A contains the background information about the teachers. Section B comprised 20 statements designed to measure the questionnaire.

In order to validate the instrument was given to experts in measurement and evaluation and their suggestions were included. To maintain the internal consistency (reliability) of a parallel test was developed and the reliability coefficient of each item obtained was very adequate.

Data Analysis

Table 1: What are the effects of COVID19 Pandemic on the academic performance of French studies?

\begin{tabular}{|l|l|r|r|}
\hline S/N & Questions & Mean & S.D \\
\hline 1 & Covid-19 made schools suspended all extra-curriculum activities. & 3.24 & .889 \\
\hline 2. & Social distancing in the classroom has affected group and team work & 3.28 & .995 \\
\hline 3. & The performance of secondary school students were at low ebb & 2.98 & 1.085 \\
\hline 4 & Social distancing does not give chance to group reading & 3.17 & .938 \\
\hline 5. & $\begin{array}{l}\text { Covid-19 has reduced the eating timetable or reduced the food ration of secondary school } \\
\text { students which affects the rate of learning }\end{array}$ & 3.01 & .912 \\
\hline & Grand mean & $\mathbf{3 . 0 2}$ & $\mathbf{0 . 9 8}$ \\
\hline
\end{tabular}

The table above indicated that the mean of 3.24 shows that Covid-19 made schools suspended all extracurriculum activities. The table also shows that mean of 3.28 reveal that Social distancing in the classroom has affected group and team work. The table above also reveal that The performance of secondary schools students were at low ebb. From the analyze data above the mean of 3.17 indicate Social distancing does not give chance to group reading. The table above shows the mean of 3.01 indicate that Covid-19 has reduced the eating timetable or reduced the food ration of secondary school students which affects the rate of learning.

This revealed from the analysis above that the grand mean is 3.02 while the bench mark is 2.5 so, we can conclude that there is effects of COVID19 Pandemic on the academic performance of French studies. 
Table 2: Does the effects of teacher attitude towards the impact of COVID19 Pandemic on the academic performance of French studies?

\begin{tabular}{|l|l|r|r|}
\hline S/N & Questions & Mean & S.D \\
\hline 1. & Selfless support for students has been reduced by Covid-19 on the academic performance & 3.24 & .979 \\
\hline 2. & $\begin{array}{l}\text { There is no more classroom relationship/social interaction between teachers and students } \\
\text { towards the academic performance in secondary schools }\end{array}$ & 2.49 & 1.061 \\
\hline 3. & Effective teaching did not really be in vogue again & 3.00 & 1.077 \\
\hline 4. & $\begin{array}{l}\text { Coronavirus has effect on suspension of internal and external examinations of students in } \\
\text { Secondary School }\end{array}$ & 3.53 & .649 \\
\hline & Grand mean & $\mathbf{3 . 0 1}$ & $\mathbf{0 . 9 0 2}$ \\
\hline
\end{tabular}

The table above indicated that the mean of 3.24 shows that Selfless support for students has been reduced by Covid-19 on the academic performance. The table also shows that mean of 2.49 reveal that There is no more classroom relationship/social interaction between teachers and students towards the academic performance in secondary schools. The table above also reveal that the mean of 3.00 shows that Effective teaching did not really be in vogue again. From the analyze data above the mean of 2.02 indicate that Coronavirus has effect on suspension of internal and external examinations of students in Secondary School. This revealed from the analysis above that the grand mean is 3.01 while the bench mark is 2.5 so, we can conclude that there is the effects of teacher attitude towards the impact of COVID19 Pandemic on the academic performance of French studies

Table 3: Does effects of student's attitude towards the impact of COVID19 Pandemic on the academic performance of French studies?

\begin{tabular}{|l|l|r|r|}
\hline S/N & Questions & Mean & S.D \\
\hline 1. & Students do not have time for assignment and class work due to Covid-19 & 3.07 & .959 \\
\hline 2. & Secondary School Student had developed low interest & 2.55 & 1.249 \\
\hline 3. & $\begin{array}{l}\text { Changes in class periods and school calendar makes secondary school students come late } \\
\text { to school }\end{array}$ & 3.29 & .691 \\
\hline 4. & Secondary school students are afraid to get close to teachers for help and support & 2.46 & 1.371 \\
\hline 5. & $\begin{array}{l}\text { Students easily forget what is being learnt in school because of the time spend in school } \\
\text { due to coronavirus }\end{array}$ & 3.08 & .822 \\
\hline & Grand mean & 2.89 & 1.02 \\
\hline
\end{tabular}

The table above indicated that the mean of 3.07 shows that Students do not have time for assignment and class work due to Covid-19. The table also shows that mean of 2.55 reveal that Secondary School Student had developed low interest. The table above also reveal that the mean of 3.29 shows that Changes in class periods and school calendar makes secondary school students come late to school. From the analyze data above the mean of 2.46 indicate that Secondary school students are afraid to get close to teachers for help and support. The table above shows the mean of 3.08 indicate that Students easily forget what is being learnt in school because of the time spend in school due to coronavirus.

This revealed from the analysis above that the grand mean is 2.89 while the bench mark is 2.5 so, we can conclude that there is effects of student's attitude towards the impact of COVID19 Pandemic on the academic performance of French studies.

\section{Conclusion}

The study reveals that an antidote to Covid 19 pandemic in French studies. Although increase in number of deaths was comparably slow in some months ago where there is evidence that more deaths might occur as new cases continue to raise every day. Numerous factors were found to have contended with preventive efforts which included poor compliance attitude, stigmatization, misconceptions and myths, fear, inadequate health facilities and others. Consequently, if stiffer preventive measures are not applied, COVID-19 in the country will continue to rise with its life threatening and economic implications.

\section{Recommendations}

Based on the findings of this study, the following recommendations were made:

- In order to ameliorate the effect of wide range COVID-19 misconceptions and myths among the people, there is urgent need for the government and other stake holders to organize well-articulated evidence based health campaigns, employing all necessary means of information dissemination, including traditional channels.

- The federal government should intensify prevention and control measures by ensuring that all states comply with the Federal government preventive orders in order to ensure uniformity of purpose.

- The government should look into the modalities adopted for relief distribution across the states, with the 
aim of ensuring that reliefs get to the target audience.

- Government might need to explore house to house testing of residents especially in states with high level of prevalence.

- The already existing laws on COVID-19 should be enforced and sanctions attached to them and implemented vigorously on defaulters in all the States in order to enhance compliance to preventive directives.

- Federal government should scale up provisions for health care facilities for COVID-19 treatment as number of cases continue to increase

- Health workers deployed to Isolation centres should be highly compensated in order to encourage hard work and more work.

- Laws against stigmatization of COVID-19 patients or survivors should be enacted and enforced by the Federal Government.

\section{REFERENCES}

Al-Rabiaah, A., Temsah, M.H., Al-Eyadhy, A.A., et al., 2020. Middle east respiratory syndrome corona virus (MERS-CoV) associated stress among medical students at a university teaching hospital in Saudi Arabia. J Infect Public Health 13, 687-691.

Auerbach, R.P., Alonso, J., Axinn, W.G., et al., 2016. Mental disorders among college students in the world health organization world mental health surveys. Psychol Med 46, 2955-2970.

Bults, M., Beaujean, D.J., Richardus, J.H., et al., 2015. Perceptions and behavioral responses of the general public during the 2009 influenza A (H1N1) pandemic: a systematic review. Disaster Med Public Health Prep 9, 207-219.

Callahan, S., Bouvard, M., 2015. Evaluation of the French version of the multidimensional scale of perceived social support during the postpartum period. Matern Child Health J 19, 1245-1251.

Cao, W., Fang, Z., Hou, G., et al., 2020. . The psychological impact of the COVID-19 epidemic on college students in China. Psychiatry Res 287, 112934. Chen, Q.,

Clin Psychol 47, 756-761. De Oliveira Araújo, F.J., de Lima, L.S.A., et al., 2020. . Impact of Sars-Cov-2 and its reverberation in global higher education and mental health. Psychiatry Res 288, 112977. Denis, A.,

Dahlem, N.W., Zimet, G.D., Walker, R.R., 1991. The multidimensional scale of perceived social support: a confirmation study.

Fiorillo, A., Gorwood, P., 2020. The consequences of the COVID-19 pandemic on mental heatlh and implications for clinical practice. Eur Psychiatry 63 (1), 1-2 e32. https ://doi.org/10.1192/j.europsy.2020.35.

Jin, Y., He, L., Kang, Y., et al., 2014. . Prevalence and risk factors of anxiety status among students aged 13-26 years. Int J Clin Exp Med 7, 4420-4426.

Johnson, J.G., Cohen, P., Pine, D.S., et al., 2000. . Association between cigarette smoking and anxiety disorders during adolescence and early adulthood. JAMA 284, 2348-2351.

Kang, Y.J., 2020. Mortality rate of infection with COVID-19 in Korea from the perspective of unerlying disease. Disaster Med Public Health Prep. 13. https://doi. org/10.1017/dmp.2020.60.

Kaparounaki, C.K., Patsali, M.E., Mousa, D.V., et al., 2020. . University students' mental health amidst the COVID-19 quarantine in Greece. Psychiatry Res 290, 113111.

Kassel, J.D., Shiffman, S., 1997. Attentional mediation of cigarette smoking's effect on anxiety. Health Psychol. $16,359-68$.

Kayotaki, E., Klein, A.M., Riper, H., et al., 2019. . Examining the effectiveness of a web-based intervention for symptoms of depression and anxiety in college students: study protocol of a randomised controlled trial. BMJ Open., e028739

Lagarde, S., Barkate, G., et al., 2016. . Rapid detection of generalized anxiety disorder and major depression in epilepsy: validation of the GAD-7 as a complementary tool to the NDDI-E in a French sample. Epilepsy Behav 57, 211-216.

Liang, M., Li, Y., et al., 2020. . Mental health care for medical staff in China during the COVID-19 outbreak. Lancet Psychiatry 7, e15-e16.

Liu, J., Zhu, Q., Fan, W., et al., 2020. . Online mental health survey in a medical college in China during the COVID-19 outbreak. Front Psychiatry 11, 459.

Liu, S., Liu, Y., Liu, Y., 2020. Somatic symptoms and concern regarding COVID-19 among Chinese college and primary school students: a cross-sectional survey. Psychiatry Res 289, 113070.

Mei, S., Yu, J., He, B., Li, J., 2011. Psychological investigation of university students in a university in Jilin Province. Med Soc 24, 84-86. Micoulaud-Franchi, J.A.,

Musiat, P., Conrod, P., Treasure, J., et al., 2014. . Targeted prevention of common mental health disorders in university students: randomised controlled trial of a transdiagnostic trait-focused web-based intervention. PLoS One 9, e93621. 
Phelan, A.L., Katz, R., Gostin, L.O., 2020. The novel coronavirus originating in Wuhan, China: callenges for global health governance. JAMA. https://doi.org/10.1001/ jama.2020.1097.

Pohl, R., Yeragani, V.K., Balon, R., et al., 1992. . Smoking in patients with panic disorder. Psychiatry Res 43, 253-262.

Regehr, C., Glancy, D., Pitts, A., 2013. Interventions to reduce stress in university students: a review and metaanalysis. J Affect Disord 148, 1-11.

Sahu, P., 2020. Closure of universities due to coronavirus disease 2019 (COVID-19): impact on education and mental health of students and academic staff. Cureus 12, e7541. 